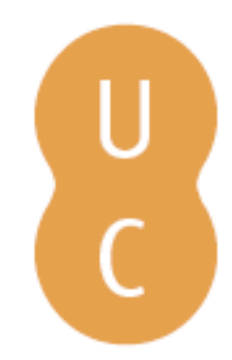

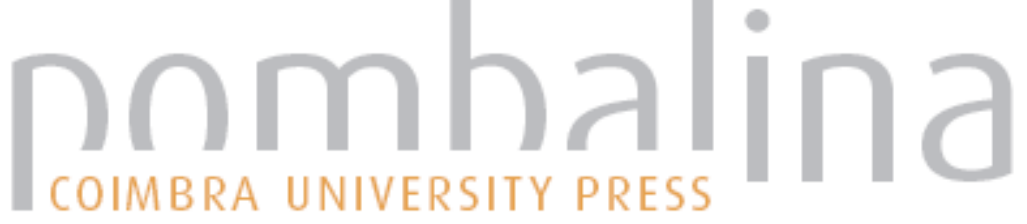

\section{Ética, política e relações internacionais}
Autor(es):
Amaral, Carlos E. Pacheco

Publicado por: Imprensa da Universidade de Coimbra

URL persistente:

URI:http://hdl.handle.net/10316.2/31593

DOI:

DOI:http://dx.doi.org/10.14195/978-989-26-0199-1_8

Accessed : $\quad$ 26-Apr-2023 10:35:45

A navegação consulta e descarregamento dos títulos inseridos nas Bibliotecas Digitais UC Digitalis, UC Pombalina e UC Impactum, pressupõem a aceitação plena e sem reservas dos Termos e Condições de Uso destas Bibliotecas Digitais, disponíveis em https://digitalis.uc.pt/pt-pt/termos.

Conforme exposto nos referidos Termos e Condições de Uso, o descarregamento de títulos de acesso restrito requer uma licença válida de autorização devendo o utilizador aceder ao(s) documento(s) a partir de um endereço de IP da instituição detentora da supramencionada licença.

Ao utilizador é apenas permitido o descarregamento para uso pessoal, pelo que o emprego do(s) título(s) descarregado(s) para outro fim, designadamente comercial, carece de autorização do respetivo autor ou editor da obra.

Na medida em que todas as obras da UC Digitalis se encontram protegidas pelo Código do Direito de Autor e Direitos Conexos e demais legislação aplicável, toda a cópia, parcial ou total, deste documento, nos casos em que é legalmente admitida, deverá conter ou fazer-se acompanhar por este aviso. 
Maria Manuela Tavares Ribeiro

Coordenação

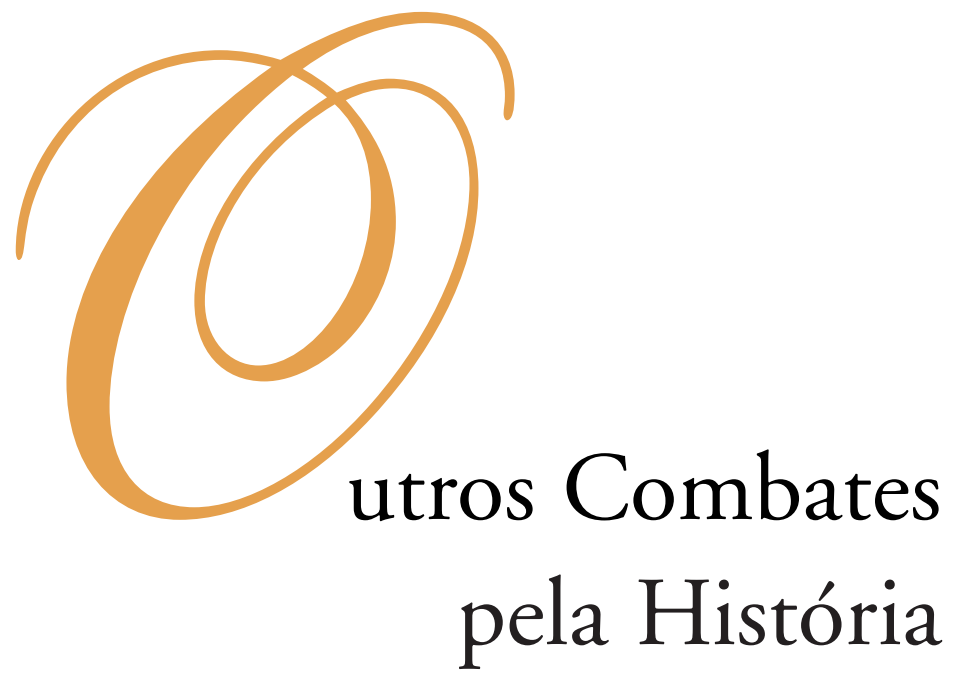




\section{COORDENAÇĀO EDITORIAL}

Imprensa da Universidade de Coimbra

Email: imprensauc@ci.uc.pt

URL: http://www.uc.pt/imprensa_uc

Vendas online: http://livrariadaimprensa.com

\section{CONCEPÇÃO GRÁFICA}

António Barros

\section{ORgANIZAÇĀO DOS TEXTOS}

Isabel Maria Luciano

Marlene Taveira

PRÉ-IMPRESSÃO

António Resende

Imprensa da Universidade de Coimbra

EXECUÇÃO GRÁFICA

SerSilito • Maia

ISBN

978-989-26-0041-3

DEPósito LEGAL

OBRA PUBLICADA COM O APOIO DE:

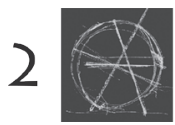

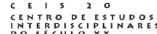

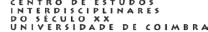

FCT Fundação para a Ciência e a Tecnologia

MINISTÉRIO DA CIÊNCIA, TECNOLOGIA E ENSINO SUPERIOR Portugal

Programa Operacional Ciência, Tecnologia, INOVAÇĀo DO QUADRo COMUNITÁRIO DE APOIO III

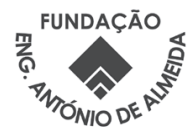

C JULHO 2010, IMPRENSA DA UNIVERSIDADE DE COIMBRA 
Maria Manuela Tavares Ribeiro

Coordenação

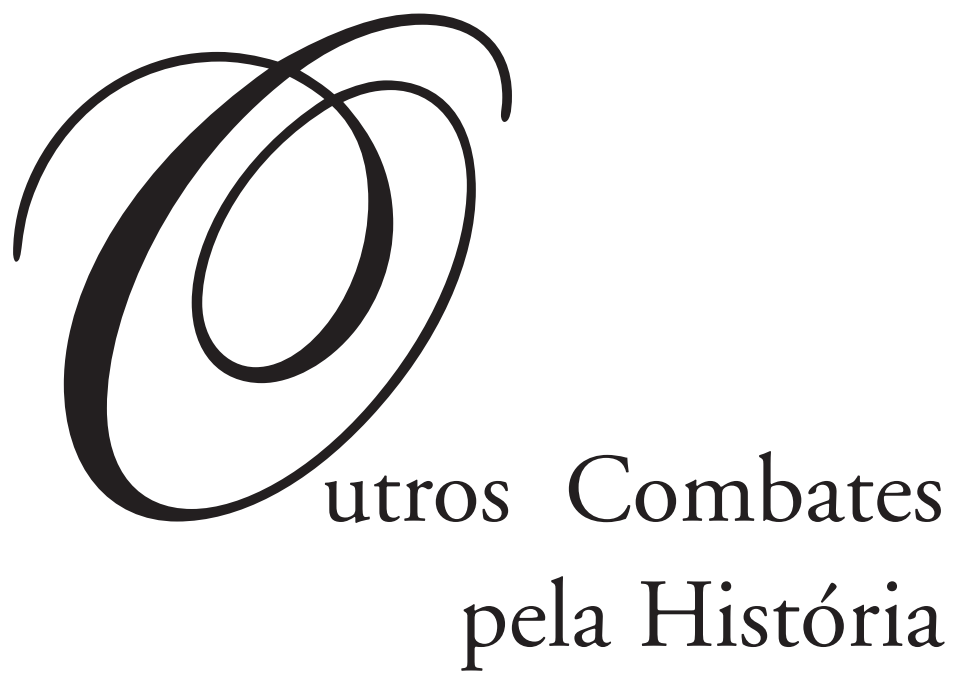

- colmbra 2010 
História e Política 


\section{Carlos E. Pacheco Amaral}

\section{Ética, Política e Relaçôes Internacionais}

Parafraseando John Locke, poder-se-á situar a mesmidade que enforma uma comunidade política na partilha de um corpus normativo comum, de índole ética, moral e, paradigmaticamente, jurídica. De igual modo, o facto de se encontrar fora do pacto social consubstanciador de uma comunidade política e, bem assim, do corpo normativo dele decorrente, atirará um homem ou um grupo de homens para a condição de alteridade subjacente ao estado de natureza - e às relaçôes internacionais - em que cada um apenas se tem a si próprio e ao poder que comanda para defender os seus interesses, fazendo justiça com as suas próprias mãos. «Vivem numa sociedade civil, uns com os outros, [escreve John Locke] todos aqueles que se encontrarem reunidos num só corpo e possuírem um sistema jurídico e judicial a que possam recorrer, com autoridade para resolver todas as controvérsias que surjam entre eles, bem como punir os transgressores» ${ }^{1}$. Na verdade, são precisamente a partilha de um corpo de direito e o reconhecimento de um juiz comum que são capazes de retirar um conjunto de homens do estado de natureza, imprimindo-lhes unidade política e elevando-os à unidade.

Ora, a celebração por comum acordo de um contrato social produz dois efeitos correlativos.

Por um lado, une num só corpo político o grupo de homens que o integram, transformando-os em iguais, já que todos se submetem voluntariamente a um mesmo corpo de direito por eles forjado - facto que irá permitir a Locke, e a toda a tradição liberal, radicar a liberdade na obediência à lei. Adoptada por comum assentimento, em vez de balizar ou de algum modo diminuir a liberdade de cada um, é a lei que permite a liberdade. Obedecendo à lei somos livres na medida em que estaremos a obedecer a normas que nós próprios legislamos. E, para além disso, é a lei que nos coloca para além do alcance da vontade arbitrária e conjuntural, seja dos membros da comunidade seja dos próprios detentores de poder ${ }^{2}$.

\footnotetext{
1 John Locke, Segundo Tratado do Governo, Lisboa, Fundação Calouste Gulbenkian, 2007, pp. 106-107.

${ }^{2}$ Cf. Ibid, em particular o capítulo IV, pp. 51-53. Numa perspectiva semelhante, Jean-Jacques Rousseau radicará a liberdade na obediência à lei, já que a sujeição à lei mais não representa do que a sujeiçãao à nossa própria vontade comum. Cf. Jean-Jacques Rousseau, O contrato social, Mem Martins, Publicações Europa-América, 1974, em especial o capítulo VI, pp. 40-43.
} 
Porém, a celebração do contrato social produz ainda um segundo efeito fundamental. Ao mesmo tempo que eleva as partes que o celebram à unidade, decorrente da partilha de uma lei comum, adoptada por consenso, e da submissão à respectiva jurisdição, atira-as para uma circunstância de alteridade face aos demais homens, quer estes tenham optado por permanecer num estado de natureza, quer se tenham reunido e celebrado um contrato social alternativo, constituindo-se, também eles, em comunidade política. Pelo facto de partilharem uma mesma lei, livremente negociada, as partes do contrato social transformam-se em concidadãos. Paralelamente, todos os demais homens se transformam em estrangeiros pelo facto de não partilharem dessa lei e de, seja permanecerem «sem lei», num estado de natureza, seja de se terem dotado de uma lei distinta e constituído uma comunidade política alternativa.

É pela celebração do contrato social nacional, diariamente sufragado, que nos afastamos do Estado de natureza, transformando-nos em concidadãos nacionais sob a protecção da lei nacional portuguesa. E o mesmo se aplica a todas as demais comunidades políticas do planeta. $\mathrm{Na}$ ausência de um contrato social que a todos congregue, seja a uma escala regional, seja à escala planetária, nenhum direito positivo está disponível para regulamentar as relações que se possam desenvolver entre estas comunidades políticas em que o planeta se constitui. Assim, da mesma maneira que a celebração do contrato social conduz, a nível interno, à emergência do direito, alicerce da cidadania, e, a nível externo, à ausência de direito característica da soberania estatal.

Por outras palavras, uma comunidade política define-se pelo facto de disponibilizar aos seus membros um corpo comum de regras para a regulamentação da respectiva convivência social e para a resolução dos conflitos que possam emergir entre eles. Já as relaçóes internacionais se definirão pela ausência de um corpo normativo que obrigue universalmente, isto é, pela inexistência de um quadro objectivo, capaz de regulamentar, de forma coerciva, as relações entre comunidades políticas independentes. Assim, enquanto os membros de uma comunidade dispóem de um sistema político, ético e jurídico, isto é, de uma hierarquia de instituições capazes de assegurar a definição, a interpretação e a aplicação de regras objectivas e aceites por todos para a regulamentação da convivência social e para a resolução de conflitos, as relações internacionais definem-se precisamente pela inexistência de um tal sistema, capaz de reunir as comunidades políticas e de garantir a resolução pacífica dos conflitos que possam surgir entre elas. Tanto assim que, enquanto a nível interno, a guerra, a guerra civil, espelha a desintegração de uma comunidade política, a nível externo, internacional, a guerra constitui o principal alicerce das relações internacionais desde os alvores das civilizaçôes.

A Bíblia, um dos mais antigos livros de Ciência Política e Relações Internacionais do Ocidente, e seguramente o mais lido, apresenta-nos esta dualidade com clareza, elevando-a à condição de instrumento exemplar para a fixação, seja da identidade de uma comunidade política, no quadro de uma mesma lei, seja da alteridade, decorrente da ausência de uma lei comum, que caracteriza as relações internacionais.

Com base numa concepção estritamente dualista do universo, o Antigo Testamento apresenta-nos, por um lado, Israel, elevado à unidade pela partilha de um mesmo corpo normativo, um mesmo conjunto de regras pelas quais a vida interna dos judeus se deverá pautar: aquelas que lhe são gradualmente disponibilizadas por Iavé, o seu Deus, e que encontrarão tradução paradigmática nas Tábuas da Lei. E será precisamente no facto de cada judeu amar o seu Deus, legislador, e guardar os seus mandamentos, que radicará a mesmidade da comunidade judaica. 
Paralelamente, à mesmidade do povo judaico corresponde a alteridade dos demais povos, decorrente do facto de adorarem outros deuses, falsos, e por isso mesmo menos poderosos do que o Deus verdadeiro de Israel, e de se organizarem no quadro dos corpos normativos próprios de cada um deles.

Deste modo, se, no seu seio, a lei de Deus eleva Israel à unidade, já nas relaçôes com os demais povos, pela alteridade que os caracteriza, essa lei é substituída pela lei da indiferença ou, melhor, pela ausência de lei, contexto em que a utilidade ou o cálculo de interesses emergem como únicos crivos para aferição do modo como os Judeus se deverão comportar com eles.

«Escuta, ó Israel! [proclama Moisés] O Senhor, nosso Deus, é o único senhor! Amarás ao Senhor, teu Deus, com toda a tua alma e com todas as tuas forças» ${ }^{3}$. É deste amor comum a Deus que decorre a unidade dos judeus, amor que é correspondido, encontrando tradução concreta, seja na série de preceitos, de leis, que Deus dá ao seu povo, seja nos pactos que com ele celebra a fim de se constituírem como o seu povo.

Assim, o mesmo Deus que exige dos Judeus que o amem reunindo-se neste culto comum, fixa as fronteiras daquele que será o seu território quando escaparem do Egipto, mandando-os "passar a cutelo» os seus inimigos, isto é, todos aqueles que se encontrarem a ocupar a terra prometida, «sem que fique nem um só» ${ }^{4}$.

Por outras palavras, à lei do amor a Deus que fixa a mesmidade interna de Israel, a nível internacional, e decorrente da alteridade que consubstancia, corresponde a lei do cutelo, da escravidão, na melhor das possibilidades, o império do poder, do cálculo de interesses e da utilização dos outros povos como instrumentos para o serviço dos superiores interesses dos Judeus.

Acresce que as relações internacionais dos judeus, as suas guerras, o seu comércio externo, etc., etc., não são, na verdade, relações entre homens concretos, isto é, entre os judeus concretos que as desenvolvem e os outros povos concretos com os quais se relacionam. Antes, e num sentido mais profundo, elas mais não serão do que manifestações concretas das verdadeiras relações que se estabelecem entre o Deus verdadeiro, por eles venerado, e os falsos deuses dos demais povos. Tanto assim que as vitórias de Israel, não são vitórias dos generais concretos que travaram a batalha, mas do seu Deus. São vitórias de Deus. E as derrotas constituirão uma espécie de instrumentos pedagógicos concretizados com o objectivo correctivo de recolocar o povo de Israel nos caminhos de Deus. Conforme é amplamente sublinhado ao longo do Antigo Testamento, os judeus nunca se encontram sozinhos. «O Senhor vosso Deus, que marcha à vossa frente, combaterá por vós, como sempre fez sob os vossos olhos no Egipto e também neste deserto, onde vistes o Senhor, vosso Deus, conduzir-vos como um pai conduz seu filho" 5 .

«Sim, [proclama Deus ao povo de Israel] se cumprirdes convenientemente toda esta lei que vos prescrevo: amar o Senhor, vosso Deus, andar sempre nos seus caminhos

\footnotetext{
3 «Livro do Deuteronómio», Capítulo 6, versículos 4 e 5, in Bíblia Sagrada, Lisboa, Difusora Bíblica,1978, p. 233.

${ }^{4}$ Cf. Ibid., Capítulo 7, versículos 1 a 6, em particular, p. 234.

${ }^{5}$ Ibid., Capítulo 1, versículos 30 e 31, p. 226.
} 
e permanecer-Lhe fiéis, o Senhor expulsará da vossa presença todas as nações e submetereis povos maiores e mais fortes do que vós». ${ }^{6}$ A lei de Deus irmana os judeus, elevando-os à condição de povo eleito, ao mesmo tempo que o demarca radicalmente da idolatria de todos os demais. Para além disso, o cumprimento dessa lei assegura a presença de Deus entre os judeus nas múltiplas actividades que desenvolvem, o que constitui garantia de sucesso ${ }^{7}$.

Esta concepção dualista judaica irá encontrar paralelo evidente nos universos grego e romano. Do mesmo modo que, para o povo de Israel, o universo conhecia duas partes distintas, por um lado os judeus e, por outro, os gentios, correspondendo a cada um deles leis radicalmente distintas, também os gregos e os romanos perspectivavam o mundo de forma dualista como sendo habitado por eles próprios, gregos, ou, mais tarde, romanos, irmanados cada um por uma lei comum, e bárbaros, todos os demais, sujeitos à lei do poder e à ordem dele decorrente.

A identidade judaica é definida pela integração na comunidade decorrente da partilha da lei de Deus. Tanto assim que o povo judaico se apresenta, até mesmo por definição, como sendo o povo de Deus. Paralelamente, os demais povos da Antiguidade apresentar-se-ão perante o Povo de Deus numa circunstância de estrita igualdade, na medida em que todos eles serão igualmente povos cuja identidade decorre do culto deste ou daquele deus falso. Nesta medida são enformados por um corpo normativo radicalmente distinto, e inferior, do qual decorre a alteridade que os caracteriza a todos.

Paralelamente até mesmo no universo helénico é cada polis que forja os seus cidadãos. E a própria religião se encontra subordinada à política, isto é, à polis.

Segundo os relatos platónicos, Sócrates representa um momento particularmente paradigmático. Ele é condenado à morte sob a acusação de corromper a juventude ateniense, desencaminhando-a dos deuses da cidade e levando-a ao culto de falsos deuses. Ora, os deuses falsos para os quais Sócrates procurou converter a juventude ateniense mais não eram do que a personalidade individual de cada um, a sua consciência, diríamos hoje, em substituição da autoridade dos poderes estabelecidos. E é, simultaneamente por se saber culpado e por ser produto de Atenas que Sócrates se recusa a fugir quando Crito lhe oferece a oportunidade para o fazer. Enquanto produto da matriz ateniense, apenas em Atenas é que consegue ser ele próprio. Fugir, ver-se atirado para fora de Atenas constituiria uma morte tão certa como tomar a cicuta, em termos espirituais, se não em termos físicos ${ }^{8}$.

Neste contexto, Antígona constitui igualmente um marco de referência. O texto de Sófocles desenvolve-se à volta da decisão de Antígona de desafiar o comando de Creonte, sepultando o irmão, Polinices. Ao fazê-lo, coloca-se acima da polis. Em vez

${ }^{6}$ Ibid., Capítulo 11, versículos 22 e 23, p. 240.

7 Cf. o modo como a presença no campo de batalha da arca da aliança, símbolo da presença de Deus entre os judeus, constituía garantia de vitória, mesmo contra exércitos manifestamente maiores e mais poderosos. Para uma visão contemporânea desta visão, atente-se às aventuras narradas por Steven Spielberg, em «Salteadores da Arca Perdida», centradas na procura da velha Arca da Aliança dos judeus, pelas garantias de vitória que asseguraria a quem a possuísse, e no empenho em que ela não caísse nas mãos de Hitler, pelas consequências catastróficas que tal acarretaria para os aliados, uma vez que equivaleria a dar a invencibilidade aos exércitos nazis.

8 Cf. Platão, Apologia de Sócrates e Críton, Lisboa, Edições 70, 2009. 
de se entender como um produto da polis, afirma deter uma identidade que lhe é anterior e superior. Tanto assim que eleva a sua consciência à condição de valor fundamental a que recorre, inclusivamente, como padrão para aferição da validade das normas produzidas pela polis. Daí o carácter trágico do texto. É que o comportamento de Antígona é de tal modo desviante ao ponto de se tornar incompreensível, até mesmo para sua irmã, Ismene, e para ela própria, que se sente como louca? 9 .

À mesmidade que aglutina atenienses, espartanos ou tebanos, elevando-os à unidade, corresponde a alteridade com que cada uma destas comunidades se perspectiva mutuamente - para já não falar dos estrangeiros, os persas, por exemplo. Segundo o relato de Túcidides, até mesmo no universo helénico, a justiça encontra-se solidamente circunscrita à condição de igualdade produzida pela partilha de um corpo de direito comum que define cada polis. Tanto assim que, conforme lembra no conhecido relato das negociações que precederam a invasão e destruição de Melos pelas forças atenienses, a justiça apenas tem lugar no seio de uma comunidade política, enquanto que, nas relações entre os povos, justo é que «os fortes exerçam o poder e os fracos se submetam àquilo a que tiverem que se submeter». Cada comunidade política produz o direito através do qual garante a justiça interna, enquanto que, a nível internacional, é da força e das relações de força entre os povos que essa mesma justiça decorre ${ }^{10}$.

Ética e Relações Internacionais são, nestes termos, conceitos alternativos, nada tendo um a ver com o outro.

Com o cosmopolitismo assiste-se ao início do desmoronamento deste quadro conceptual. Primeiro, com o estoicismo, e, de forma definitiva com o cristianismo. Ao reclamar para seu irmão, como uma louca, segundo o coro, um direito superior àquele proclamado pela polis, Antígona representa aqui um momento exemplar. E, mais tarde, ao afirmar a unidade fundamental de todo o género humano, e, por isso mesmo, o ideal da respectiva reunião numa mesma comunidade política da dimensão do planeta no quadro de um ius inter-gentius natural comum, o estoicismo anunciaria um modelo novo de organização social e política e, bem assim, um novo paradigma de relações internacionais. Será, no entanto, com o cristianismo que o paradigma antigo se irá exaurir, definitivamente, sendo substituído por outro novo.

O cristianismo opera uma dupla revolução nos nossos modelos de organização social e política, ao mesmo tempo personalizante e universalizante. Personalizante, na medida em que se passará a insistir na afirmação do valor intrínseco da personalidade de cada ser humano, independentemente da comunidade política que possa integrar. E universalizante, na medida em que, em vez de dirigida a um povo eleito, a Boa Nova cristã se abre necessariamente a todos os homens e a todos os povos.

Assim acontece na medida em que o cristianismo assenta sobre um ideal de igualdade fundamental de todo o género humano. Conforme lembra São Paulo, em Cristo todas as clivagens que possam ser adoptadas para a fixação de desigualdade entre os homens são superadas. "Porventura Deus só o é dos judeus? [pergunta na "Carta aos

\footnotetext{
${ }^{9}$ Cf. Sófocles, Antígona, trad. de Maria Helena da Rocha Pereira, Porto, Centro de Estudos Humanísticos da Universidade do Porto, 1958.

${ }^{10}$ Cf. Túcidides, História da Guerra do Peloponeso, Brasília, Editora Universidade de Brasília, 1986, p. 282 .
} 
Romanos"] Sim, também dos gentios, pois há um só Deus, que justificará pela fé os circuncisos e que também pela fé justificará os incircuncisos» ${ }^{11}$, elevando-os a ambos à unidade cosmopolita. Com o cristianismo assiste-se à afirmação da liberdade e da igualdade fundamentais de todo o género humano. Conforme São Paulo esclarece na Carta aos Gálatas, pela fé em Cristo, todos os homens acedem à condição de filhos de Deus. Com Cristo, «não há judeu nem grego; não há servo nem livre, não há homem nem mulher». Todos os crentes são "um só em Cristo» ${ }^{12}$.

No paradigma antigo, a identidade e o próprio ser de cada um decorrem da comunidade política em que se insere e na qual se forja. Já na perspectiva cristã, cada um transporta consigo uma carga identitária, na qual a sua personalidade e a sua dignidade se alicerçam, que é anterior e, por isso mesmo, independente da comunidade política em que se possa inserir. Essa carga identitária original decorre tanto do facto de todos os homens serem filhos de Deus, e não apenas alguns, como de serem feitos à imagem e semelhança de Deus. Enquanto «templo de Deus» ${ }^{13}$, cada ser humano constitui, à partida, uma espécie de microcosmos que espelha o macrocosmos divino - facto que se impõe à comunidade política em que se possa vir a situar, qualquer que ela seja.

Assim, ao dualismo antigo, nos termos do qual o planeta era perspectivado como encontrando-se dividido entre concidadãos e estrangeiros, judeus e gentios, romanos e bárbaros, cada um com a sua lei, o cristianismo irá propor uma matriz fundamentalmente monista que, no limite, apontará para o encadeamento de toda a humanidade na unidade da fé em Cristo. E, a um tal monismo universalista religioso, a medievalidade irá fazer corresponder um monismo social e político, apontando para a reunião de todos os homens numa comunidade política comum, a respublica christiana universalis generis humani, uma comunidade política da dimensão do género humano.

Ao dualismo da Antiguidade correspondia a clivagem radical entre Política e Relações Internacionais. Para a mentalidade antiga a Política é, até mesmo por definição, aquela actividade desenvolvida dentro da comunidade, dentro da polis, na matriz Ocidental, pelos polites, os cidadãos. Ela encontrava-se, portanto, circunscrita à polis, perspectivada como comunidade autárquica, por um lado, responsável pelo próprio ser dos respectivos polites, e, por outro, capaz de lhes disponibilizar tudo aquilo de que poderiam necessitar para viverem a vida boa, que merece ser vivida. Fora dela, o que encontramos é a alteridade radical, o vazio axiológico sobre o qual se desenrolam as Relaçôes Internacionais, isto é, as actividades, bélicas ou pacíficas, entre comunidades que se inter-relacionam com vista ao serviço dos respectivos interesses específicos.

Política e Relações Internacionais constituem, portanto, duas categorias ou actividades substancialmente distintas e que de modo algum se poderão confundir. A primeira, a Política, reportando-se às condições necessárias para a vida boa, que merece ser vivida, atira-nos para o império da lei, da moral e da justiça. Com a segunda, as Relações Internacionais, vemo-nos atirados para um universo onde a única lei,

\footnotetext{
${ }^{11}$ Cf. Bíblia Sagrada, op. cit., "Carta aos Romanos», Capítulo 3, versículos 29 a 31, p. 1487.

12 Cf. Ibid., "Carta aos Gálatas», Capítulo 3, versículo 28, p. 1535.

13 Ibid., "Carta aos Coríntios», Capítulo 3, versículo 16.
} 
moral e justiça disponíveis são as que decorrem das relações de força. Daí o objecto específico de estudo das Relações Internacionais: a Paz e a Guerra.

Já na concepção medieval, em virtude do monismo universalista que a enforma, esta clivagem esbate-se, ao ponto de se esboroar. Na perspectiva cristã, todos os seres humanos partilham uma natureza e um destino comuns, e as suas actuaçôes encontram-se, de facto, regulamentadas por uma mesma lei natural que, pela sua essência, se projecta para além da capacidade de acção de toda e qualquer comunidade política que se possa estabelecer. Quer isto dizer que as Relaçôes Internacionais de modo algum podem ser perspectivadas como detendo uma matriz substancialmente distinta das actividades que se desenvolvem entre cidadãos numa mesma comunidade. No momento em que a polis perde a condição de comunidade autárquica, as mesmas razões que, segundo Aristóteles, exigem a reunião das pessoas individuais em famílias, destas em aldeias, e das aldeias em poleis, passam a exigir, no dizer de São Tomás de Aquino, a integração das poleis, em províncias, reinos até à constituição, no limite, da respublica universalis. Deste modo, as Relaçôes Internacionais, isto é as relações entre regna, enquadradas que estão na respublica christiana, passam a deter uma natureza semelhante àquelas que se desenvolvem entre as demais unidades políticas, começando pelos cidadãos na base. Por outras palavras, num tal contexto monista de integração planetária, as Relações Internacionais mais não são do que uma manifestação concreta da Política.

Na perspectiva dualista grega, platónica como aristotélica, a política é a actividade pública desenvolvida pelos polites, os cidadãos, visando a construção da vida boa, que merece ser vivida, num ambiente concreto: a polis. Ora, tal como o amor é o vínculo que reúne marido e mulher, na primeira instância em que a natureza social e política dos seres humanos se manifesta — a família —, também a polis, enquanto manifestação última deste mesma condição humana exige um elemento de aglutinição e de definição: a amizade. Assim, do mesmo modo que a oikos, a família, será a comunidade que integra aqueles que se amam - marido, mulher, filhos ${ }^{14}$, também a polis se apresenta como a comunidade dos amigos — os polites — que são amigos uns dos outros e solidários uns para com os outros. E, tal como onde, em vez de amor, imperar o ódio ou a indiferença, deixaremos de nos encontrar perante uma família para nos depararmos com vizinhos ou estranhos, a partir do momento em que deixarmos um universo de amizade, pública, deparar-nos-emos, necessariamente, com um universo de inimizade, pública, isto é, com estrangeiros. Por outras palavras, nesse preciso momento, sairemos de uma polis e encontrar-nos-emos no estrangeiro.

É assim que, para os antigos, o limiar da política, isto é, da actividade que se desenvolve na polis, situa-se na linha de fronteira que separa o amigo do inimigo. Tal como, aliás, o limiar da família se situa na linha que separa o amante do indiferente, ou do odiado.

Acresce que, do mesmo modo que cada um reserva todo o seu amor para os seus familiares, outra coisa não se entenderia, também cada um reserva, em exclusivo, sentimentos como a amizade, a solidariedade, a confiança para os seus concidadãos.

\footnotetext{
${ }^{14} \mathrm{E}$, por analogia, os instrumentos de que dispõe para cumprir a sua missão: o lar, os animais domésticos e os escravos.
} 
É assim que os concidadãos, os polites, são os amigos, enquanto que, todos os demais, os estrangeiros, são inimigos. Inimigos, em sentido público, hostis, não inimicus, conforme a tradição romana viria a sublinhar seguindo de perto, aliás, a tradição grega clássica.

Conforme Platão sublinha no livro V d'A República, em sentido estrito, o outro do ateniense, o estrangeiro, não é o espartano ou o tebano. Na medida em que todos partilham de nomoi comuns, isto é, de um mesmo corpo civilizacional e de direito, todos integram uma mesma comunidade política: «a raça helénica». Nestes termos, o outro, o estrangeiro o «inimigo natural», conforme esclarece, comum de todos é o persa e o bárbaro, em geral. O espartano pode ser o «inimigo» do ateniense, mas apenas conjunturalmente, em sentido figurado, nunca em sentido pleno. Tanto assim que guerra, em sentido estrito, um ateniense apenas a pode travar com um estrangeiro, um persa ou um bárbaro. Em sentido estrito, um conflito entre Esparta e Atenas não pode consubstanciar um estado de guerra, mas apenas de "discórdia civil», do mesmo modo que, em vez de inimizade entre ambas, se deverá falar de "sedição» 15 .

Daí os dois universos paralelos que o mundo antigo nos disponibilizava: da Política e das Relações Internacionais. O primeiro, regulamentando as relações entre amigos, públicos, através da lei comum que os reunia em comunidade, traduz-se no império da lei ${ }^{16}$. O segundo, reporta-se aos inimigos, públicos, espelhando a ausência da lei, e encontrando tradução concreta na guerra e nas actividade diplomática e consular.

O cristianismo introduz-nos num universo distinto, onde não há lugar para clivagens entre os homens, já que todos são irmãos em Cristo e onde, segundo a parábola do bom samaritano, cada um se torna no próximo de todos os demais. Eliminada a concepção em que o outro, seja ele romano ou samaritano, se apresenta como inimigo, então ele apenas pode ser um outro eu, um amigo, que, como eu, é igualmente chamado a integrar a respublica christiana universalis.

A própria filosofia política genuinamente medieval, abre-se, com naturalidade, a todas as manifestações da actividade política, incluindo, como é óbvio, aquela que se desenvolve entre os vários reinos, sempre no quadro axiológico monista proposto pela matriz civilizacional cristã. Tanto é assim que os manuais de Relaçôes Internacionais contemporâneos comummente situam o surgimento desta disciplina na Antiguidade, indiana, chinesa, judaica e greco-romana. Porém, é habitual saltarem sobre o período medieval, apontando o seu renascimento com Maquiavel, a modernidade estatal e a ruptura que então se estabelece com aquilo que alguns já apelidaram de «teoria política ética» da Idade Média ${ }^{17}$.

E, de facto, aquilo que a medievalidade ocidental nos propõe é submissão de toda a política a uma ética universal: a ética cristã. Para a matriz política da Antiguidade, a ética, em vez de unitária e universal, apresentava-se de forma situada, contexto em

15 Cf. Platão, A República, tradução de Maria Helena da Rocha Pereira, Lisboa, Fundação Calouste Gulbenkian, 1987, 470 b e c, p. 247.

16 Para utilizar a expressão adoptada por Ronald Dworking para título da sua obra, Law's Empire, publicada em Cambridge, Massachusetts, em 1986, pela Belknap Press of Harvard University Press.

17 Cf. por exemplo, James Dougherty e Robert Pfaltzgraff, Jr., Relaçöes Internacionais. As teorias em confronto, Lisboa, Gradiva, 2003, em especial as pp. 11 e seguintes sobre «as primeiras abordagens à teoria das relações internacionais». 
que assumia tantas modalidades quantas as comunidades políticas disponíveis. Assim se explica que, no paradigma antigo, a ética derive da política. A ética, a moral e até mesmo a religião não só se encontram dentro da alçada do poder político, como são por ele definidas e delimitadas. Com a medievalidade cristã, assiste-se à inversão desta equação. A ética, a moral, a religião, são projectadas solidamente para além da pluralidade de manifestaçôes concretas do político e reduzidas à unidade jusnaturalista. E a política passa a ser enformada por um tal corpus normativo que a transcende. É, aliás, em função de uma tal unidade normativa superior capaz de enquadrar as múltiplas formas do político que a medievalidade conheceu, imprimindo-lhes uma unidade superior, que emergem o ideal cosmopolita medieval, a ideia de Europa e de humanidade, os direitos humanos, a autonomia, a subsidiariedade, e uma pluralidade de conceitos nos dias de hoje tão acarinhados ${ }^{18}$.

A modernidade irá introduzir-nos num terceiro momento, ou patamar. Em alternativa ao ideal unitário e cosmopolita medieval a Europa moderna ficará marcada precisamente pela pulverização do corpus normativo medieval de vocação unitária em termos éticos, religiosos e jurídicos e de matriz cosmopolita, responsável pela aglutinação, até à unidade, do complexo caleidoscópio de unidades políticas diferenciadas, autónomas na sua especificidade, mas integradas até à unidade planetária. Tanto assim que, em substituição do ideal imperial cosmopolita, se assiste à consolidação das novas unidades políticas do sistema, os Estados-nação, cada um cioso da sua soberania e, por isso mesmo, da sua capacidade demiúrgica de se apresentar como o alfa e ómega de tudo e de todos os que se encontram no seio das suas fronteiras territoriais. E, em alternativa à concepção unitária e integrada do cosmos e da igual dignidade de todos os seres humanos, procede-se à recuperação do dualismo da Antiguidade, e da cosmovisão que a enformava. Por outras palavras, será o tema da morte de Deus - criador e redentor de toda a humanidade - e da sua substituição pelo próprio homem, isto é, pelo Estado, perspectivado à maneira hobbesiana como grande Leviatã, ou como deus mortal cada um criador dos seus cidadãos e único responsável pelo respectivo devir —, que melhor captará o princípio norteador do modelo moderno de organização social e política.

Cujus regio ejus religio, é como a modernidade proclamará a inversão dos termos em que dantes se operava a relação entre a política, por um lado, e o direito, a ética, por outro. No quadro conceptual da Idade Média, o direito, a ética e a religião assumiam uma projecção universal, irmanando todos os homens num mesmo destino comum, para cujo cumprimento todos se encontravam solidariamente integrados. Agora, com a modernidade, é cada Estado que, de forma soberana, se dota do corpo de direito através do qual se deverá enformar e afirmar na sua singularidade. Do direito, da ética e, no limite, até mesmo da religião.

Recorrendo à já velha tradição do contrato social, a modernidade irá substituir o pluralismo e o universalismo que dantes se impunham na concepção medieval pela singularidade da vontade soberana das novas entidades políticas que se constituem, os Estados soberanos. Como que numa recuperação do paradigma proposto pela

18 Para uma perspectiva sinóptica do pensamento político medieval, cf. Ralph Lerner e Mushin Mahdi, eds., Medieval Political Philosophy, Ithaca, New York, Cornell University Press, 1963. 
Antiguidade, assiste-se ao abandono final do duplo ideal medieval de autonomia e de unidade, primeiro universal e, depois, até mesmo europeia, no quadro de um mesmo modelo de ordem, jurídica, ética e religiosa. Em sua substituição, a modernidade irá apostar na simplicidade da ideia de soberania e, correlativamente, na visão de um planeta esquartejado em Estados soberanos, todo poderosos, a nível interno, e radicalmente iguais uns aos outros, a nível externo, sem que nada, nem ninguém, se lhes imponha.

Reemerge a clivagem radical separando a política interna, a política desenvolvida por cada Estado no seu seio, da política externa, das relaçôes internacionais, e, por esta via, a clivagem correspondente entre Ciência Política e Relações Internacionais. Por força do princípio de soberania que o enforma, cada Estado ergue-se como autêntica ilha de direito e de moral, no quadro de um oceano caracterizado por um vazio axiológico radical. É num tal quadro axiologicamente neutro que se movimenta, relacionando-se com os demais Estados, seus pares, na medida em que considera poder daí retirar qualquer proveito ou servir o seu interesse nacional. São exclusivamente os Estados que produzem soberanamente o direito e a moral que vigora no seu seio e através dos quais se definem, e que, para além daqueles que são específicos de cada Estado, nenhuma moral, nenhum direito, poderá ser descortinado entre eles ${ }^{19}$.

Superiorem non recognoscit, assim se afirma cada Estado nas relações internacionais que desenvolve. As pessoas individuais são sujeitos morais detentores de direitos e de deveres, mas apenas na medida em que situam no quadro normativo de uma comunidade estatal. Os Estados, porém, não o são. Cada Estado emerge como criador dos seus cidadãos e, correlativamente, produtor e garante dos direitos de que se possam reclamar. Assim, é para com os seus cidadãos, e apenas para com eles, que a cada Estado podem ser imputados deveres. Parafraseando os Embaixadores atenienses, segundo o relato de Tucídides, e a concepção platónica e aristotélica apresentada no início deste estudo, já no século XX, Reinhold Niebuhr sublinha que «enquanto indivíduos, os homens acreditam que se devem amar e servir uns aos outros e estabelecer a justiça nas suas relaçôes mútuas. Enquanto comunidades raciais, económicas e nacionais, cada uma toma para si tudo aquilo que o poder que comanda lhe permitir» ${ }^{20}$.

É, conforme explicita, a "tragédia do espírito humano»: os códigos normativos - de índole jurídica ou moral — são aplicáveis apenas no seio das comunidades políticas organizadas em que emergem e que os conseguem sancionar através do poder coercitivo que comandam. Conforme Maquiavel já nos havia proposto, a modernidade introduz-nos num universo de ruptura com a Idade Média, designadamente em termos normativos e da relação entre Ética, Política e Relaçôes Internacionais. Quer em termos jurídicos, quer em termos éticos, opera-se uma autonomização radical do político, contexto em que as novas unidade políticas do sistema, os Estados soberanos, não só

19 Para uma exploração detalhada da matriz moderna do Estado soberano e do modo como contrasta com o modelo medieval de organização social e política cf. o nosso livro Do Estado soberano ao Estado das autonomias. Regionalismo, subsidiariedade e autonomia para uma nova ideia de Estado, Porto, Afrontamento, 1998, em especial o capítulo I, pp. 29 a 111 e a extensa bibliografia ali indicada.

${ }^{20}$ Reinhold Niebuhr, Moral Man and Immoral Society. A study in Ethics and Politics, New York, Charles Scribner's Sons, 1932, p. 9. 
passam a forjar livremente o direito por que se regem - sem quaisquer amarras a consideraçōes de direito natural — como se adoptam uma moral privativa — igualmente liberta da moral tradicional de raiz religiosa, isto é, católica ${ }^{21}$.

Por outras palavras, como que numa recuperação da matriz Antiga, o direito e a moral, em vez de universais, são, de novo, situados e circunscritos a cada uma das comunidades políticas do planeta e, em vez de as transcenderem, são perspectivados como decorrendo da respectiva vontade soberana, derivar deles. Reemerge a clivagem entre, por um lado, Política, a actividade que se desenvolve dentro de cada Estado, regulamentada pelo quadro normativo, moral e jurídico, por ele desenvolvido para o efeito, e, por outro, Relações Internacionais, isto é as relações desenvolvidas pelas comunidades políticas que integram o sistema, os Estados soberanos, num vazio axiológico radical onde o princípio utilitário do serviço do interesse nacional esgota o quadro normativo de que o estadista dispõe para regulamentar o seu relacionamento com outros Estados, igualmente soberanos.

Tanto assim que, para definir a essência do político, Carl Schmitt retoma a díade antiga de amigo e inimigo. "A clivagem especificamente política a que podem ser reduzidas todas as acçôes políticas é a de "amigo e inimigo» 22 . Do mesmo modo que a estética se define pela díade belo/feio, a medicina pela de saúde/doença, a moral pela de bem/mal, ou a economia pela díade lucro/prejuízo, também a política encontra tradução na díade amigo/inimigo. Isto é, conforme esclarece, «a distinção entre amigo e inimigo denota o máximo grau de intensidade de uma união ou de uma separação, de uma associação ou de uma dissociação [...] o inimigo político não carece de ser mau, em termos morais, ou feio, em termos estéticos, não é necessário que se apresente como nosso concorrente em termos económicos, podendo inclusivamente ser útil travar relações comerciais com ele. Ele é, no entanto, um outro, um estrangeiro» ${ }^{23}$.

$\mathrm{O}$ facto de alguém ser bom ou mau, belo ou feio, rico ou pobre, ou de apresentar estas ou aquelas características, físicas ou morais, é absolutamente irrelevante, para o situar em termos políticos. A única dimensão verdadeiramente relevante para o efeito é aquela que se prende com a questão de saber de que lado da fronteira essa pessoa se situa, que comunidade estatal integra, e, por isso mesmo, se é amigo ou inimigo — não em termos sentimentais, mas em termos públicos. Até os direitos de uma pessoa, civis, políticos, sociais, e económicos, variam consoante a comunidade política que integra.

Como que em recuperação do dualismo antigo, a modernidade estatal irá reorganizar a política segundo as duas categorias de amigo e de inimigo, de cidadão e de estrangeiro, reservando a ética e o direito, em exclusivo, para os primeiros. Já ao nível dos segundos, a nível externo, internacional, a guerra permanece o único instrumento disponível para identificação da justiça e do direito, seja em termos éticos, seja em termos jurídicos. Até mesmo por definição, já que a guerra, em sentido estrito, é actividade que se desenvolve entre estrangeiros, inimigos, públicos.

\footnotetext{
${ }^{21}$ Para uma introdução ao pensamento político de Maquiavel e à revolução que opera em termos da relação entre política, direito e moral, derivando as segundas da primeira, cf. o nosso ensaio «Sob o signo de Maquiavel: a nova ordem e moral política», in Arquipélago, Filosofia, n. ${ }^{\circ}$ 1, 1990, pp. 89-110.

22 Cf. Carl Schmitt, The Concept of the Political, Chicago, Chicago University Press, 1996, p. 26.

23 Ibid., pp. 26-27.
} 
Enquanto cidadãos individuais, todos nós detemos uma panóplia de direitos e de deveres para com o nosso próximo, os nossos concidadãos, com os quais partilhamos as nossas vidas no quadro da comunidade estatal que nos forjou e na qual situamos o nosso próprio ser, desde logo, na medida em que nos definimos como sendo portugueses, espanhóis ou belgas. Já os deveres do Estadista, no entanto, dirigem-se, em exclusivo, para a comunidade cujos destinos lhe foram confiados. Daí que o Embaixador tenha a obrigação de negociar o tratado que melhor servir os interesses da sua comunidade estatal e o Primeiro-Ministro tenha a obrigação de se envolver no sistema internacional para dele procurar retirar o máximo possível de benefícios para os seus concidadãos - independentemente do impacto que essas actividades possam ter sobre os demais Estados, os respectivos cidadãos, ou o que quer que seja, a não ser que daí decorram consequências importantes para o seu Estado e os seus concidadãos no futuro. É o confronto radical entre política, desenvolvida no seio de cada Estado, e Relações Internacionais, travadas entre Estados. A primeira reporta-se ao universo da ética e da solidariedade, as segundas transportam-nos para os antípodas do Imperativo Categórico kantiano, convocando-nos a perspectivar os nossos interlocutores internacionais sempre como objectos, como instrumentos para a gratificação dos nossos interesses, nunca fins em si mesmos, como sujeitos portadores de dignidade própria.

Acresce que, conforme Niebuhr esclarece ainda, «O poder sacrifica a justiça à paz dentro das comunidades e destrói a paz entre comunidades [...] A história da humanidade é testemunho eloquente do facto que o poder que impede a anarquia nas relaçôes internas dos grupos encoraja a anarquia nas relações entre grupos» ${ }^{24}$, muito particularmente quando assumem a forma de Estados soberanos. Por força do sistema de direito de que se dota e a enforma, a comunidade estatal consubstancia uma hierarquia que contrasta com a anarquia de um sistema internacional composto por soberanias nacionais. Uma anarquia em que, conforme recorda Cálicles, "a própria natureza sublinha a justiça de o melhor tirar proveito do pior, o mais capaz do menos. E tanto entre todos os animais como em todos os Estados e raças da humanidade, isto é por demais evidente: a justiça é reconhecida como sendo a soberania e o proveito do mais forte sobre o mais fraco" ${ }^{25}$. Faltando-lhe objectividade e coercibilidade, o direito internacional pouco mais constituirá, portanto, do que um estratagema desenvolvido pelos fracos para tentarem amarrar, condicionar e diminuir os fortes.

Nestes termos o direito produzirá resultados antagónicos nos domínios interno e externo. No quadro da polis como no quadro do Estado, é instrumento de justiça. Já a nível internacional conduzirá à injustiça. O que leva as comunidades políticas - na Grécia Antiga, Atenas, por exemplo, como na modernidade, a Inglaterra, a Rússia ou os Estados Unidos - a desafiarem o direito internacional, sempre que isso é considerado adequado para o serviço dos respectivos interesses. A política externa norte-americana, lembrou o Presidente George Bush por ocasião da crise do Iraque, não será definida em Nova Iorque, na Organização das Nações Unidas, mas em Washington, pelos órgãos de governo próprio dos Estados Unidos, e para o cumprimento do respectivo interesse nacional.

\footnotetext{
${ }^{24}$ Reinhold Niebuhr, op. cit., p. 16.

25 Platão, Gorgias, in Plato, The Collected Dialogues, Edited by Edith Hamilton e Huntington Cairns, Princeton, Princeton University Press, Bollingen Series LXXXI, 1961. A citação encontra-se em 483 d, p. 266.
} 
O poder soberano do Estado transforma as comunidades nacionais em domínios de ordem e âmbitos específicos da justiça, e paralelamente, nas Relações Internacionais apenas se abre espaço para um instrumento de ordem e de justiça internacional: a guerra. Tal como para o mundo antigo, também para a modernidade a guerra emerge, no limite, como instrumento de ordem e de justiça, cumprindo ao nível internacional papéis paralelos àqueles que, a nível interno, são desempenhados pelos tribunais. Uma vez que os órgãos de poder do Estado dominam a totalidade do poder disponível, a nível interno, estatal, não pode haver dúvidas, nem hesitações, e a ordem e a justiça encontram-se asseguradas. Já a nível internacional, na medida em que as relações de poder entre os Estados são sempre cambiantes, a guerra não só não é um mal como constitui uma necessidade mais ou menos permanente, já que se apresenta como o único instrumento disponível, seja para aferir o poder relativo de cada um dos Estados que integram o sistema, seja para dirimir os conflitos que possam surgir entre eles, seja para fixar a justiça e o modelo de ordem internacional.

E, no entanto, o século XX trouxe a inviabilização da guerra, pelo menos entre grandes potências. Os 78 milhões de vítimas, directas e indirectas, das duas guerras mundiais são disso a prova mais eloquente.

A partir da segunda metade do último século tornou-se imperativo forjar um modelo novo de Relaçôes Internacionais, capaz de superar o carácter adversativo e de alteridade radical para onde o modelo moderno tradicional atirava os Estados. A inviabilidade do velho sistema de equilíbrio de poder, alianças flutuantes, consórcio de nações à maneira de Viena, de Paris ou de Nova Iorque tem vindo a ficar por demais evidente. Se bem que o modelo imperial medieval não apresente particular atractividade para os dias de hoje, torna-se evidente a necessidade de nos dotarmos de um modelo político alternativo àquele que herdámos da modernidade. Um modelo que corresponda à realidade actual e às exigências globais que ela nos coloca, a primeira das quais se prende com a desintegração da díade identitária mesmidade, alteridade, correspondente a duas realidades antagónicas, estatal e internacional.

Tal como, a nível interno, a política deixou de ser monopólio do Estado, também as relaçôes internacionais, a nível externo, deixaram há muito de ser relaçōes entre Estados, para se alargarem a um caleidoscópio de entidades, incluindo os cidadãos individuais, - sem que os Estados detenham quaisquer possibilidades de controlar as actividades concretas em que se traduzem. Hoje, o próximo de cada um, o conjunto daqueles com os quais se tem de conviver para se viver bem, a vida boa, que merece ser vivida, não se reduz ao conjunto dos seus concidadãos, antes se abre, no limite, a toda a humanidade. Assim, o direito, a moral, a solidariedade não poderão deter uma dimensão estritamente nacional, dado que assumem uma projecção planetária. Urge, portanto, reconciliar a ética com a política e com as relações internacionais.

Os direitos e deveres de cada um não se encontram confinados às fronteiras da respectiva comunidade nacional, antes, no dizer de Stanley Hoffman, se projectam para além delas, reportando-se à própria condição humana, independentemente do local no planeta que uma pessoa possa habitar ${ }^{26}$. Cumpre-se a visão de Séneca, do

\footnotetext{
${ }^{26}$ Reportamo-nos ao importante trabalho pioneiro que publicou, já em 1981, em Siracusa, na Syracuse University Press intitulado Duties Beyond Borders. On the limits and possibilities of ethical international politics.
} 
planeta como «casa comum dos deuses e de todos os homens». Falta imprimir-lhe forma. Transfigurar o político. Desenvolver um quadro de ordem adequado a esta nova realidade nos termos do qual a velha clivagem entre Política e Relações Internacionais, entre «amigos» e «inimigos» se esboroe e a comunidade dos «amigos» se abra a toda a humanidade. No Velho Continente, o projecto de integração europeia constitui um passo paradigmático nessa direcção. A reforma da Organização das Nações Unidas será outro, mas apenas se decorrer, como no caso da União Europeia, de uma reconfiguração do modelo moderno de Estado soberano e, correlativamente, do sistema internacional que engendrou.

Mas esse será tema para outra reflexão.

\section{BIBLIOGRAFIA}

Amaral, Carlos E. Pacheco, «Sob o signo de Maquiavel: a nova ordem e moral política», in Arquipélago, Filosofia, n. ${ }^{\circ} 1,1990$.

—, Do Estado soberano ao Estado das autonomias. Regionalismo, subsidiariedade e autonomia para uma nova ideia de Estado, Porto, Afrontamento, 1998.

BÍBLIA SAGRADA, Lisboa, Difusora Bíblica, 1978.

Dougherty, James e Robert Pfaltzgraff, Jr., Relaçōes internacionais. As teorias em confronto, Lisboa, Gradiva, 2003.

DwORKING, Ronald, Law's Empire, Cambridge, Massachusetts, Belknap Press of Harvard University Press, 1986.

HofFman, Stanley, Duties Beyond Borders. On the limits and possibilities of ethical international politics, Syracuse, Syracuse University Press, 1981.

Lerner, Ralph e Mushin Mahdi, eds., Medieval Political Philosophy, Ithaca, New York, Cornell University Press, 1963.

LOCKE, John, Segundo Tratado do Governo, trad. de Carlos E. Pacheco Amaral, Lisboa, Fundação Calouste Gulbenkian, 2007.

NiebuHr, Reinhold, Moral Man and Immoral Society, New York, Charles Scribner's Sons, 1932.

PlatÃo, A República, tradução de Maria Helena da Rocha Pereira, Lisboa, Fundação Calouste Gulbenkian, 1987.

-, Apologia de Sócrates e Críton, Lisboa, Edições 70.

—, Gorgias, in Plato, The Collected Dialogues, Edited by Edith Hamilton and Huntington Cairns, Princeton, Princeton University Press, Bollingen Series LXXXI, 1961.

Rousseau, Jean-Jacques, O contrato social, Mem-Martins, Publicaçōes Europa América, 1986.

Schmitt, Carl, The Concept of the Political, Chicago, Chicago University Press, 1996.

Sófocles, Antígona, trad. de Maria Helena da Rocha Pereira, Porto, Centro de Estudos Humanísticos da Universidade do Porto, 1958.

The Political IdeAs of St. Thomas Aquinas, New York, Hafner Press, 1953. 

Série

Documentos

Imprensa da Universidade de Coimbra

Coimbra University Press

2010

- U

C • 